contains 6-methyloctanoic acid. By applying polymyxin acylase $^{5}$, which was isolated from soil bacteria, to circulin B, deacyl circulin B was obtained. From the acid hydrolysate of DNP-derivative of deacyl circulin B, diDNP-Dab was detected as the $N$-terminal amino acid, and the molar ratios of free amino acids in the acid hydrolysate of DNP-derivative of circulin B were found to be Thr:Leu:Ile:Dab $=2: 1: 1: 1$. These results suggested that circulin $B$ does not have the structure proposed by KOFFLER and KOBAYASHI ${ }^{2}$.

Then, using our technique with Nagarse ${ }^{3}$ (subtilo peptidase A, EC 3.4.4.16), we obtained the following fragments : (I) Ioa $\rightarrow(\alpha) \mathrm{Dab} \rightarrow \mathrm{Thr}$, (II) Ioa $\rightarrow(\alpha) \mathrm{Dab} \rightarrow \mathrm{Thr} \rightarrow$ ( $\alpha$ ) Dab, (III) Dab, (IV) a cyclic heptapeptide having the molar ratios of amino acids of Thr:Leu:Ile:Dab = $1: 1: 1: 4$. Applying the SANGER's DNP method to IV we detected $\alpha$-DNP-Dab, which could not be found in the completely dinitrophenylated circulin B. The AKABORI's hydrazinolysis method ${ }^{6}$ failed to find the carboxy terminal amino acid of peptide IV. The Rf value of IV was identical with that of the cyclic heptapeptide obtained from circulin A by the enzymatic hydrolysis using Nagarse, by comparison with their Rf values in paper chromatography. In addition, considering the chemical structures of other polymyxin series antibiotics ${ }^{4}$, the amino acid sequence of peptide IV was found to be cyclo $(y) \mathrm{Dab} \rightarrow(\alpha) \mathrm{Dab} \rightarrow \mathrm{Leu} \rightarrow \mathrm{Ile} \rightarrow(\alpha) \mathrm{Dab} \rightarrow(\alpha) \mathrm{Dab} \rightarrow$ $\mathrm{Thr} \rightarrow$.

On the basis of these results, circulin B has a similar structure to circulin $\mathrm{A}$ as shown in Scheme 2 and only differs from circulin $\mathrm{A}$ in having Ioa in place of Moa.

Zusammenfassung. Es wird über die Strukturaufklärung von Circulin B, einem Antibiotikum aus Bacillus circulans ATCC 14040 , berichtet, dem die Formel des Schemas 2 zulkommt.

K. Hayashi, Y. Suketa and T. SUzukI

Institute for Protein Research, Osaka

University, Osaka (Japan), 26 March 7968.

5 T. Suzuki, Y. Kimura and K. Iwadare, Jap. Patent Gazette 12, 101 (1966)

6 S. Akabori, K. Ohno and K. Narita, Bull. Chem. Soc. Japan $25,214(1952)$

\title{
The Synthesis of a Natural Dinucleoside Phosphate Derivative with the Aid of a Purine Cyclonucleoside
}

In a previous communication ${ }^{1}$ we described the use of an $8,5^{\prime}-a$-purine cyclonucleoside for the synthesis of a dinucleoside phosphate. As this procedure yielded a product having a hydroxyl group at position 8 of the purine moiety, it was of interest to study the opening of the anhydro linkage of an $8,5^{\prime}$-S-purine cyclonucleoside by the attack of a nucleoside phosphate anion. Such an approach would lead to the formation of a dinucleoside phosphate with a mercapto group at position 8 of the purine nucleus, which could be removed by treatment with Raney $\mathrm{Ni}$, thus resulting in a product having no unnatural substituents.

8, 5'-Anhydro-8-mercapto-2'-o-mesylguanosine ${ }^{2}(200 \mathrm{mg})$ was, therefore, refluxed with 1.2 equivalents of tri-n-butyl ammonium $3^{\prime}$-uridylate in dry DMF for $14 \mathrm{~h}$. The dinucleoside phosphate, uridyl-(3'-5')-8-mercapto-2'-o-mesylguanosine (I), was isolated by preparative paper chromatography on Whatman $3 \mathrm{~mm}$ paper $^{3}$ in $41 \%$ yield. Rf, $0.37 ; \lambda, 0.1 N \mathrm{HCl}-265.5,295$ (sh) $\mathrm{nm} ; 0.1 \mathrm{~N} \mathrm{NaOH}$ 268, $285(\mathrm{sh}) \mathrm{nm}$. Formic acid hydrolysis of this product gave uracil and 8-mercaptoguanine. Paper chromatographic analysis of the snake venom phosphodiesterase

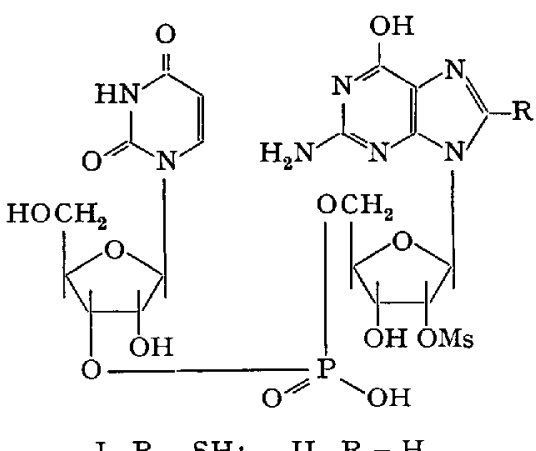

I. $\mathrm{R}=\mathrm{SH} ; \quad \mathrm{II}, \mathrm{R}=\mathrm{H}$ hydrolysate showed that uridine and another substance, presumably 8-mercapto-2'-o-mesylguanosine-5'-phosphate, were formed. That the methyl sulphonate group at the $2^{\prime}$ position in the purine cyclonucleoside was not displaced (or displaced only to a very small extent) by the phosphate anion was shown by the presence of absorption at $1170 \mathrm{~cm}^{-1}$ (Nujol) in the IR-spectrum of I. This is consistent with an observation made earlier that it is difficult to remove this group ${ }^{2}$.

Uridyl-(3'-5')-8-mercapto-2'-o-mesylguanosine (I) was refluxed with Raney $\mathrm{Ni}$ in aqueous ethanol $(1: 1)$ for $3.5 \mathrm{~h}$. Filtration of the catalyst and evaporation of the solvent yielded uridyl- $\left(3^{\prime}-5^{\prime}\right)-2^{\prime}-0$-mesylguanosine (II) in $75 \%$ yield, Rf $0.40^{3} ; \lambda_{\max }, 0.1 \mathrm{~N} \mathrm{HCl}-260,0.1 N \mathrm{NaOH}-262 \mathrm{~nm}$. This product contained sulphur, had mesyl absorption in the IR and yjelded guanine and uracil on formic acid hydrolysis ${ }^{4}$.

Zusammenfassung. Die Behandlung von 8-5'-Anhydro8-mercapto-2'-o-mesylguanosin mit (1,2 Äquivalent) Trjbutylammonium-uridylat in siedendem DMF lieferte das Dinucleosidphosphat Uridyl-(3'-5')-8-mercapto-2'-o-mesylguanosin. Weitere Behandlung mit Raney $\mathrm{Ni}$ führte zum Uridyl-(3'-5')-2'-o-mesylguanosin.

\section{P. C. Srivastava, K. L. Nagpal and M. M. DhaR}

Central Drug Research Institute, Lucknow (India), 4 March 7968.

1 K. L. NAGPAI and M. M. DHAR, Tetrahedron Lett, 47 (1968).

2 M. Ikehara, H. Tada and K. Muneyama, Chem. pharm. Bull., Tokyo 13, 639 (1965).

3 Descending paper chromatography, solvent: $n$-butanol-acetic acidwater $(4: 1: 5)$.

4 Communication No. 1252 from the Central Drug Research Institute. 